\title{
HUBUNGAN PENGETAHUAN DAN PERILAKU VULVA HYGIENE SAAT MENSTRUASI DENGAN KEJADIAN PRURITUS VULVAE PADA REMAJA PUTRI KELAS VII DI SMP NEGERI 1 SEPULU BANGKALAN
}

\author{
Annah Hubaedah \\ Dosen Prodi D-III Kebidanan Fakutas IImu Kesehatan Universitas PGRI Adi Buana Surabaya \\ Jl. Dukuh Menanggal XII, Surabaya \\ Email: annah@unipasby.ac.id
}

\begin{abstract}
ABSTRAK
Pruritus vulvae merupakan gangguan yang ditandai dengan rasa gatal pada alat kelamin eksternal perempuan. Pruritus vulvae bisa disebabkan oleh bakteri, jamur, dan virus.Tujuan penelitian ini adalah untuk mengetahui hubungan antara pengetahuan dan perilaku tentang vulva higiene saat menstruasi dengan kejadian pruritus vulvae pada remaja putri kelas VII di SMP Negeri 1 Sepulu Bangkalan.

Penelitian ini menggunakan metode penelitian observasional dengan pendekatan cross sectional. Populasi adalah seluruh remaja putri kelas VII SMP Negeri 1 Sepulu Bangkalan sebanyak 98 orang. Sampel diperoleh sebanyak 79 orang yang ditentukan dengan teknik simple random sampling. Alat ukur yang digunakan adalah kuesioner. Uji statistik menggunakan Lambda $\rho \leq 0,05$. Hasil penelitian menunjukkan bahwa ada hubungan antara pengetahuan tentang vulva higiene $(p=0,028<\alpha=0,05)$ dan perilaku tentang vulva higiene $(p=0,006<\alpha=0,05)$ saat menstuasi dengan kejadian pruritus vulvae pada remaja putri kelas VII di SMP Negeri 1 Sepulu Bangkalan.

Untuk itu, perilaku vulva hygiene pada remaja putri harus ditingkatkan karena perilaku vulva hygiene yang baik, akan mengurangi kejadian pruritus vulvae.
\end{abstract}

Kata Kunci: Pengetahuan, Perilaku, Vulva Higiene, Menstruasi, Pruritus vulvae

\begin{abstract}
Pruritus vulvae is a desease indicated by intching on the external female genitalia. Pruritus vulvae can be caused by bacteria, fungi and viruses. The aim of this research is to investigate the relationship between knowledge and behavior of vulva hygiene during menstruation with pruritus vulvae events on teenage-girls in class VII at SMP Negeri 1 Sepulu Bangkalan.

This research employs observasional research method by using cross sectional approach. The population of this research is all female students in class VII at SMP Negeri 1 Sepulu Bangkalan as much as 98 students. The samples are obtained as much as 79 students determined by simple random sampling technique. Questioners are used as the instrument of this research. Besides, it statistically uses lambda.

The result showed that there was a relationship between knowledge of vulva hygiene $(p=0.028<\alpha=0.05)$ and behavior of vulva hygiene $(p=0.006<\alpha=0.05)$ events during menstruation with pruritus vulvae on teenage-girls in class VII at SMP Negeri 1 Sepulu Bangkalan.

Therefore, behavior of vulva hygiene during menstruation are necessary to be increased since having proper, behavior of vulva hygiene will decrease pruritus vulvae events risk.
\end{abstract}

Key words: Knowledge, Behavior, Vulva hygiene, menstruation, Pruritus vulvae 


\section{PENDAHULUAN}

Masa remaja merupakan masa dimana remaja mengalami perkembangan dan pematangan organ reproduksi. Salah satu ciri khas kematangan organ reproduksi adalah menstruasi. Pada usia yang sangat muda akses informasi tentang menstruasi sangat terbatas, baik dari orang tua, sekolah maupun media massa. "Budaya tabu" dan anggapan bahwa remaja akan mengetahui sendiri masalah reproduksi seperti menstruasi masih berkembang luas di dalam masyarakat, sehingga hal tersebut membatasi pengetahuan remaja tentang menstruasi khususnya vulva hygiene. Perilaku vulva hygiene saat menstruasi yang kurang tepat akan terus dianut oleh remaja putri dari hari ke hari. Remaja akan sering mengabaikan kebersihan genetalia karena minimnya pemahaman tentang hygiene menstruasi.

Akibat perilaku hygiene yang kurang tepat mengakibatkan dampak yang buruk bagi kesehatan reproduksi. Salah satu masalah yang sering dialami remaja saat menstruasi adalah pruritus vulvae. Pruritus vulvae merupakan gejala gatal parah dan iritasi disekitar vulva. Perilaku hygiene yang buruk menyebabkan jamur dan bakteri tumbuh subur, dan menyebabkan rasa gatal serta iritasi pada daerah di sekitar vulva. Bila infeksi tersebut dibiarkan dan tidak diobati dengan sempurna, akan menimbulkan infeksi seperti infeksi kandida akut, vaginosis bakteri dan trikomoniasis (Indah, 2012). Penelitian yang dilakukan oleh Indah (2012) di SMA Negeri 1 Ngimbang Lamongan pada remaja putri menunjukkan bahwa, 79 orang (100\%) pernah mengalami pruritus vulvae saat menstruasi. Dimana sebanyak 15,2\% selalu merasakan pruritus vulvae setiap hari selama menstruasi dan sebanyak $84,8 \%$ mengalami pruritus vulvae tidak setiap hari selama menstruasi. Sedangkan penelitian yang dilakukan oleh Winerungan, E.M (2013) menunjukkan bahwa dari 167 remaja putri di SMP Negeri 8 Manado, 107 orang $(64,1 \%)$ mengalami gatal dan penelitian yang dilakukan Fitriya (2014) menunjukkan bahwa dari 59 remaja putri di wilayah kerja puskesmas Pisangan, sebesar 36 orang (61\%) mengalami gatal-gatal di daerah kemaluan.

Berdasarkan hasil wawancara pada 10 orang siswi kelas VII di SMP Negeri 1 Sepulu pada tanggal 4 Februari 2017, diperoleh data yang menunjukkan bahwa 7 siswi $(70 \%)$ merasakan gatal pada alat kelamin saat menstruasi, dan 3 siswi (30\%) tidak merasakan gatal pada alat kelamin saat menstruasi.

Pruritus vulvae adalah gangguan yang ditandai dengan sensasi gatal parah dari alat kelamin eksternal perempuan (Indah, 2012). Penyebab pruritus vulvae adalah infeksi, invasi (skabies, pedikulosis pubis, Enterobius vermicularis), dan dermatitis kotak (iritan dan alergik). Untuk meredakan rasa gatal yang mengganggu perlu diketahui dulu penyebabnya. Dengan menghilangkan penyebab gatal maka 
keluhan juga akan hilang. Menghindari penyebab gatal dapat dengan selalu menjaga kebersihan di area kemaluan, gunakan air bersih ketika cebok atau gunakan tisue steril, gunakan pakaian dalam tidak ketat dan terbuat dari bahan katun. Dengan menghindari penggunaan sabun, semprot dan pengharum vagina serta jenis obat- obatan yang dapat mengiritasi permukaan kemaluan. Lebih baik gunakan sabun bayi yang lembut dan bukan sabun wangi atau deterjen. Beberapa resep tradisional juga bisa untuk mengatasi gatal pada vagina.

Pruritus vulvae sering terjadi pada remaja saat menstruasi. Hal ini dikarenakan pada saat menstruasi area genetalia menjadi lebih lembab. Saat menstruasi darah dan keringat keluar serta menempel pada vulva, jika pada saat itu remaja tidak menjaga kebersihan genetalia dengan benar, jamur dan bakteri yang akan tumbuh subur sehingga menyebabkan rasa gatal. Rasa gatal yang berlebihan membuat remaja tak tahan ingin menggaruknya. Sedangkan bila digaruk, permukaan kulit akan lecet, terbuka dan meradang.

Vulva hygiene saat menstruasi kemungkinan besar dipengaruhi oleh tingkat pengetahuan tentang kesehatan reproduksi. Rendahnya pengetahuan tentang kesehatan reproduksi akan memungkinkan perempuan tidak berperilaku hygiene pada saat menstruasi dan dapat membahayakan kesehatan reproduksinya sendiri.
Salah satu perilaku yang sangat ditekankan bagi remaja yang tengah mengalami menstruasi adalah pemeliharaan kebersihan area genetalia. Hygiene saat menstruasi dapat dilakukan dengan cara mengganti pembalut setiap 4 jam sekali atau 3 sampai 4 kali dalam sehari, setelah mandi atau buang air, membasuh vagina dari arah depan kebelakang anus dan vagina dikeringkan dengan tisu atau handuk agar tidak lembab. Pemakaian celana dalam yang baik terbuat dari bahan yang mudah menyerap keringat (Maidartil, dkk, 2016). Pendidikan mengenai kesehatan reproduksi, khususnya tentang vulva hygiene saat menstruasi sudah seharusnya diberikan di sekolah. Hal ini dilakukan untuk mencegah bias pengetahuan tentang kesehatan reproduksi di kalangan remaja. Pihak sekolah harus berkerjasama dengan lintas sektoral seperti dinas kesehatan dan puskesmas untuk memberikan penyuluhan tentang kesehatan reproduksi untuk meningkatkan pemahaman, sikap, dan perilaku positif remaja putri tentang kesehatan reproduksi, khususnya tentang vulva hygiene, guna meningkatkan derajat kesehatan reproduksinya.

\section{METODE PENELITIAN}

Penelitian ini merupakan penelitian observasional, dengan uji Lambda dengan $\rho$ $\leq 0,05$. Pengambilan data dilakukan dengan cara primer. Populasi dalam penelitian ini adalah semua siswi kelas VII di SMP Negeri 1 Sepulu sebanyak 98 orang yang sudah 
menstruasi. Teknik sampling menggunakan simple random sampling,

Sampel dalam penelitian ini menggunakan rumus solvin dengan jumlah sampel sebanyak 79 dan memenuhi kriteria inklusi (1) siswi yang sehat, (2) siswi yang sudah mengalami menstruasi (3) bersedia dilakukan penelitian. Dan memenuhi kriteria eksklusi (1) siswi yang tidak berada ditempat (2) menolak berpartisipasi.

Penelitian ini dilakukan di SMP Negeri 1 Sepulu Kecamatan Sepulu Kabupaten Bangkalan, pada bulan Maret-Juni 2017. Instrumen penelitian ini adalah kuesioner untuk menilai pengetahuan dan perilaku vulva hygiene saat menstruasi dan kejadian pruritus vulva. Data yang telah dikumpulkan akan dilakukan tabulasi data, dan analisa data dengan menggunakan uji model loglinier dengan $\rho \leq 0,05$. Uji statistika Lambda digunakan untuk data yang memiliki 2 variabel bebas yang berskala ordinal dan memiliki 1 variabel terikat yang berskala nominal (Nursalam, 2013).

\section{HASIL PENELITIAN}

Hasil penelitian didapatkan dari populasi 98 siswi, setelah dilakukan pengambilan sampel dengan teknik simple random sampling maka responden yang didapatkan sejumlah 79 orang
A. Data Umum

Tabel 1. Distribusi frekuensi umur responden

\begin{tabular}{ccc}
\hline $\begin{array}{c}\text { Umur } \\
\text { (tahun) }\end{array}$ & $\begin{array}{c}\text { Jumlah } \\
\text { (siswi) }\end{array}$ & $\begin{array}{c}\text { Persentase } \\
(\%)\end{array}$ \\
\hline $12-13$ & 45 & 57 \\
$14-15$ & 33 & 41,8 \\
$16-17$ & 1 & 1,3 \\
\hline Total & $\mathbf{7 9}$ & $\mathbf{1 0 0}$ \\
\hline
\end{tabular}

Berdasarkan tabel diatas diketahui bahwa sebagian besar remaja putri berumur 12-13 tahun sebanyak 45 (57\%).

B. Data Khusus

\section{Pengetahuan.}

Tabel 2. Distribusi frekuensi tingkat pengetahuan tentang vulva hygiene saat menstruasi pada remaja putri

\begin{tabular}{ccc}
\hline Pengetahuan & $\begin{array}{c}\text { Jumlah } \\
\text { (siswi) }\end{array}$ & $\begin{array}{c}\text { Persentase } \\
(\%)\end{array}$ \\
\hline Kurang & 41 & 51,9 \\
Cukup & 24 & 30,4 \\
Baik & 14 & 17,7 \\
\hline Total & $\mathbf{7 9}$ & $\mathbf{1 0 0}$ \\
\hline
\end{tabular}

Berdasarkan tabel diatas
menunjukkan bahwa sebagian besar
pengetahuan remaja putri tentang vulva
hygiene saat menstruasi tergolong dalam
kategori kurang yaitu sebesar 41 orang
$(51,9 \%)$.

2. Perilaku.

Tabel 3. Distribusi frekuensi perilaku vulva hygiene saat menstruasi pada remaja putri

\begin{tabular}{ccc}
\hline Perilaku & $\begin{array}{c}\text { Jumlah } \\
\text { (siswi) }\end{array}$ & $\begin{array}{c}\text { Persentase } \\
(\%)\end{array}$ \\
\hline Kurang & 50 & 63,3 \\
Cukup & 22 & 27,8 \\
Baik & 7 & 8,9 \\
\hline Total & $\mathbf{7 9}$ & $\mathbf{1 0 0}$ \\
\hline
\end{tabular}


Tabel 3 menunjukkan bahwa sebagian besar perilaku remaja putri tentang vulva hygiene saat menstruasi tergolong dalam kategori kurang yaitu sebesar 50 orang $(63,3 \%)$.

\section{Kejadian pruritus vulvae}

Tabel 4. Distribusi frekuensi kejadian pruritus vulvae pada remaja putri.

\begin{tabular}{lcc}
\hline $\begin{array}{l}\text { Kejadian } \\
\text { PV }\end{array}$ & $\begin{array}{c}\text { Jumlah } \\
\text { (siswi) }\end{array}$ & $\begin{array}{c}\text { Presentase } \\
\text { (\%) }\end{array}$ \\
\hline Ya & 59 & 74,7 \\
Tidak & 22 & 25,3 \\
\hline Total & $\mathbf{7 9}$ & $\mathbf{1 0 0}$ \\
\hline
\end{tabular}

Tabel 4 diketahui bahwa sebagian besar remaja putri yang mengalami pruritus vulvae saat menstruasi sebanyak 59 orang $(74,7 \%)$.

\section{Hasil Tabulasi Silang}

Tabel 5 Tabulasi silang pengetahuan vulva hygiene saat menstruasi dengan kejadian pruritus vulvae remaja putri

\begin{tabular}{llll}
\hline Pengetahuan & \multicolumn{2}{c}{ Kejadian PV } & Jml \\
\cline { 2 - 3 } $\begin{array}{c}\text { vulva } \\
\text { hygiene }\end{array}$ & \multicolumn{1}{c}{ Tidak } & Ya & \\
\cline { 2 - 4 } Kurang & 0 & $\sum$ & $\Sigma$ \\
Cukup & 9 & 41 & 41 \\
Baik & 11 & 3 & 24 \\
\hline Total & $\mathbf{2 0}$ & $\mathbf{5 9}$ & $\mathbf{7 9}$ \\
\hline
\end{tabular}

Tabel 5 menunjukkan bahwa dari 41 remaja putri dengan pengetahuan vulva hygiene kurang didapatkan 41 orang (100\%) mengalami pruritus vulvae. 24 remaja putri dengan pengetahuan cukup didapatkan 15 orang $(62,5 \%)$ mengalami pruritus vulvae, 9 orang $(37,5 \%)$ tidak mengalami pruritus vulvae, dan 14 remaja putri dengan pengetahuan baik didapatkan 3 orang mengalami pruritus vulvae dan 11 orang $(78,6 \%)$ tidak mengalami pruritus vulvae. Dari hasil statistik Uji Lambda diperoleh nilai $p$ value 0,028 ( $p<a 0,05)$, berarti Ho ditolak dan $\mathrm{H} 1$ diterima.

Tabel 6 Tabulasi silang perilaku vulva hygiene saat menstruasi dengan kejadian pruritus vulvae pada remaja putri.

\begin{tabular}{|c|c|c|c|}
\hline \multirow{3}{*}{$\begin{array}{l}\text { Perilaku } \\
\text { vulva } \\
\text { hygiene }\end{array}$} & \multicolumn{2}{|c|}{ Kejadian PV } & \multirow{2}{*}{ Jml } \\
\hline & $\frac{\text { Tida }}{\Gamma}$ & $\frac{Y a}{\Gamma}$ & \\
\hline & $\Sigma$ & $\Sigma$ & $\Sigma$ \\
\hline Kurang & 3 & 47 & 50 \\
\hline Cukup & 10 & 12 & 22 \\
\hline Baik & 7 & 0 & 7 \\
\hline Total & 20 & 59 & 79 \\
\hline
\end{tabular}

Tabel 6 menunjukkan bahwa sebanyak 50 remaja putri dengan perilaku vulva hygiene kurang didapatkan 47 orang (94\%) mengalami pruritus vulvae, 3 orang (6,0\%) tidak. mengalami pruritus vulvae. 22 orang remaja putri dengan perilaku vulva hygiene cukup didapatkan 12 orang (54,5\%) mengalami pruritus vulvae, 10orang (45,5\%) tidak mengalami pruritus vulvae. Dan 7 orang dengan perilaku vulva hygiene yang baik didapatkan 7 orang (100\%) tidak mengalami pruritus vulvae. Dari hasil statistik Uji Lambda diperoleh nilai $p$ value $0,006(p<a 0,05)$.

\section{PEMBAHASAN}

Pengetahuan tentang vulva hygiene saat menstruasi pada remaja putri kelas VII di

\section{SMPN 1 Sepulu Bangkalan}

Sebagian besar pengetahuan remaja putri tentang vulva hygiene saat menstruasi tergolong dalam kategori kurang yaitu sebesar 41 orang $(51,9 \%)$. 
Pengetahuan merupakan hasil pengindraan manusia, atau hasil tahu seseorang terhadap objek melalui indra yang dimilikinya. Kebenaran pengetahuan diperoleh dengan cara memecahkan masalah yang dihadapi pada masa lalu. Semakin tinggi tingkat pengetahuan akan tercermin pada perilaku sehari-hari (Notoadmojo, S 2012). Beberapa faktor yang menyebabkan kurangnya pengetahuan adalah umur dan pendidikan. Usia juga dapat mempengaruhi pengetahuan seseorang, usia erat hubungannya dengan tingkat kedewasaan teknik maupun psikologis. Semakin bertambahnya usia maka berbanding lurus dengan pengetahuan yang dimiliki seseorang.

Pendidikan merupakan suatu proses pembentukan kecepatan seseorang secara intelektual dan emosional ke arah alam dan sesama manusia (Notoadmodjo, 2012). Semakin tinggi pendidikan seseorang maka diharapkan pengetahuan dan keterampilan akan semakin meningkat.

Proses belajar dipengaruhi berbagai faktor dari dalam seperti motivasi dan faktor luar berupa sarana informasi yang tersedia, serta keadaan sosial budaya. Seseorang yang memiliki sumber informasi yang lebih banyak akan memiliki pengetahuan yang lebih luas pula (Prawirohardjo, 2009).

Berdasarkan penelitian yang dilakukan dilapangan didapatkan bahwa banyak remaja putri yang memiliki pengetahuan hygiene menstruasi yang kurang dikarenakan berbagai macam faktor, salah satunya adalah umur. Pada penelitian ini, umur remaja putri berkisar antara 12-13 tahun dimana usia tersebut termasuk kategori masa remaja awal. Remaja awal mengalami perkembangan psikologis dimulai dari sikap penerimaan pada perubahan kondisi fisik, berkembangnya cara berpikir namun bersikap overestimate. Pada tahap ini remaja menganggap hygiene menstruasi tidaklah begitu penting, sehingga mereka tidak mencari tahu tentang hal-hal yang berkaitan dengan kesehatan reproduksi mereka.

Faktor lain yang mempengaruhi kurangnya pengetahuan remaja putri kelas VII di SMPN 1 Sepulu Bangkalan adalah kurangnya informasi tentang hygiene menstruasi. Masyarakat menganggap kesehatan reproduksi masih tabu dibicarakan oleh remaja. Hal tersebut membatasi komunikasi antara orang tua dan remaja tentang menstrual hygiene. Akibatnya, remaja kurang mengerti, kurang memahami dan kadang-kadang mengambil keputusan yang salah mengenai kesehatan reproduksi. Selain itu, remaja kelas VII tidak mendapatkan informasi tentang hygiene menstruasi di sekolah. Pelajaran tentang sistem reproduksi baru akan diberikan saat remaja menginjak kelas VIII.

Media massa juga memiliki peran penting dalam menyampaikan informasi tentang hygiene menstruasi. Salah satu media massa yang sangat berperan adalah internet. Banyak remaja yang sudah menggunakan internet untuk mengakses 
berbagai informasi. Tetapi, kebanyakan remaja tidak mengoptimalkan fungsi dari alat tersebut, remaja putri lebih suka mengakses informasi diluar kesehatan. Semakin remaja putri terbuka dalam mengakses informasi mengenai hygiene menstruasi, maka akan semakin luas wawasan dan pemahaman mengenai kesehatan reproduksi. Dengan pengetahuan yang baik, remaja putri akan merespon menstruasi dengan hal-hal atau perilaku hygiene yang positif.

\section{Perilaku tentang vulva hygiene saat menstruasi pada remaja putri kelas VII di SMPN 1 Sepulu Bangkalan.}

Sebagian besar perilaku remaja putri tentang vulva hygiene saat menstruasi tergolong dalam kategori kurang yaitu sebesar 50 orang $(63,3 \%)$.

Green (1980) dalam Notoatmodjo (2012) mencoba menganalisa perilaku manusia dari tingkat kesehatan. Kesehatan seseorang atau masyarakat dipengaruhi oleh 2 faktor pokok, yakni faktor perilaku dan faktor diluar perilaku. Selanjutnya, perilaku itu sendiri ditentukan oleh 3 faktor, yaitu faktor predisposisi, yang terwujud dalam pengetahuan, sikap, kepercayaan, nilai-nilai dan sebagainya, faktor pendukung yang terwujud dalam lingkungan fisik, tersedia atau tidaknya fasilitas-fasilitas atau saranasarana kesehatan dan faktor pendorong, yang terwujud dalam sikap dan perilaku petugas kesehatan, atau petugas lain yang merupakan kelompok referensi dari perilaku masyarakat. Teori Green dalam penelitian ini akan digunakan untuk memprediksi bahwa pengetahuan akan mempengaruhi sikap yang kemudian menentukan baik buruknya perilaku seseorang untuk meningkatkan kesehatannya.

Berdasarkan penelitian yang dilakukan di lapangan, faktor yang mungkin menyebabkan perilaku hygiene menstruasi remaja putri kelas VII di SMPN 1 Sepulu adalah kurangnya pengetahuan remaja putri tentang vulva hygiene. Pengetahuan remaja mengenai kesehatan reproduksi cenderung yang belum adekuat, menyebabkan mereka memiliki perilaku hygiene menstruasi yang kurang tepat, sebab menurut Hani (2011) pengetahuan yang positif dan negatif akan mempengaruhi perilaku seseorang. Dengan pengetahuan yang benar akan hygiene saat menstruasi, maka akan merubah sikap remaja putri dan mempengaruhi perilaku saat melakukan hygiene menstruasi. Pengetahuan baik mendorong perilaku yang baik dan benar sedangkan pengetahuan yang kurang atau salah akan mengakibatkan perilaku yang tidak benar juga.

Selain itu, pola pemikiran dan keyakinan tentang hygiene menstruasi juga mempengaruhi perilaku remaja putri. Remaja sering meremehkan praktik hygiene menstruasi, karena mereka meyakini bahwa dengan praktik hygiene yang biasa dilakukan tidak akan berdampak pada kesehatan reproduksi mereka. Mereka menganggap bahwa praktik hygiene yang mereka lakukan sudah tepat dan benar, sehingga mereka mempertahankan perilaku 
tersebut. Pemikiran dan keyakinan yang benar akan berdampak pada perilaku yang benar pula, jadi diperlukan pemberian health education pada remaja putri untuk meningkatkan pengetahuan, pemikiran dan keyakinan, sehingga terjadi perubahan perilaku kesehatan (vulva hygine) yang lebih baik.

\section{Kejadian pruritus vulvae pada remaja} putri kelas VII di SMPN 1 Sepulu Bangkalan

Sebagian besar remaja putri mengalami pruritus vulvae saat menstruasi sebanyak 60 orang (75,9\%). Berdasarkan hasil jawaban kuesioner remaja putri tentang kejadian pruritus vulvae, didapatkan data bahwa mayoritas remaja putri mengalami pruritus vulvae di awal menstruasi yaitu sebesar 45 orang (57\%), remaja putri mengalami pruritus vulvae tidak setiap menstruasi sebesar 37 orang (46,8\%), dan remaja putri merespon pruritus vulvae dengan cara menggaruk sebesar 38 orang $(48,1 \%)$.

Indah (2010) mengatakan, pruritus vulvae merupakan gangguan yang ditandai dengan sensasi gatal pada alat kelamin eksternal perempuan. Pruritus vulvae dipengaruhi oleh praktik hygiene menstruasi dan sarana kebersihan rumah. Wanita yang mengalami pruritus vulvae sering kali memiliki perawatan vulva yang kurang baik.

Pada saat menstruasi darah dan keringat yang keluar menempel pada vulva sehingga daerah genetalia menjadi lembab.
Jamur Candida albican, Trichomonas vaginalis, Gardnerella vaginalis yang berada di daerah genetalia tumbuh subur dan menyebabkan rasa gatal dan infeksi pada daerah tersebut.

Berdasarkan penelitian yang dilakukan di lapangan, faktor yang mungkin menyebabkan prurius vulvae saat mensruasi adalah perilaku hygiene. Sebagian besar responden mempunyai praktik hygiene yang kurang baik seperti membersihkan alat kelamin dari arah belakang ke depan, menggunakan sabun daun sirih, menggunakan celana dalam yang ketat saat menstruasi. Ketidaktahuan remaja putri dalam merawat dan membersihkan alat kewanitaan ini, dapat memicu berkembangbiaknya jamur ataupun bakteri, hal ini yang menyebabkan remaja putri mengalami pruritus vulvae. Pruritus vulvae merupakan salah satu gejala yang bisa menyebabkan terjadinya infeksi vaginalis, seperti infeksi kandida akut, vaginosis bakteri dan trikomoniasis. Jika remaja putri tidak memiliki imunitas yang baik maka infeksi akan segera terjadi. Oleh karena itu selain meningkatkan perilaku hygiene menstruasi, remaja juga harus meningkatkan imunitas tubuh untuk mencegah terjadinya pruritus vulvae dan infeksi.

Hubungan pengetahuan tentang vulva hygiene saat menstruasi dengan kejadian Pruritus vulvae 
Berdasar hasil tabulasi silang pengetahuan dan kejadian pruritus vulvae menunjukkan bahwa remaja putri dengan pengetahuan vulva hygiene kurang sebanyak 41 orang, seluruhnya (100\%) mengalami pruritus vulvae. Sedangkan 24 orang dengan pengetahuan cukup sebanyak 15 orang $(62,5 \%)$ mengalami pruritus vulvae dan 9 orang $(37,5 \%)$ tidak mengalami pruritus vulvae. Dan sebanyak 14 orang yang memiliki pengetahuan baik sebanyak 3 orang $(21,4 \%)$ mengalami pruritus vulvae dan 11 orang $(78,6 \%)$ tidak mengalami pruritus vulvae.

Tingginya pengetahuan tentang kesehatan organ reproduksi wanita, tidak menjamin mempunyai perilaku yang baik untuk meningkatkan status kesehatannya.

Penelitian yang dilakukan di SMAN 1 Ngimbang Lamongan pada 79 siswi kelas $X$ dan XI menunjukkan bahwa ada hubungan yang signifikan antara praktik hygiene menstruasi dengan kejadian pruritus vulvae saat menstruasi dengan $p=0,001 \quad(p<\alpha$ $(0,05)$.

Hal ini sesuai dengan penelitian di lapangan, remaja putri yang memiliki pengetahuan baik dan cukup belum tentu tidak mengalami pruritus vulvae saat menstruasi. Hal ini dikarenakan kejadian pruritus vulvae saat menstruasi tidak hanya dipengaruhi oleh faktor pengetahuan saja, akan tetapi juga dipengaruhi oleh praktik hygiene. Remaja putri yang memiliki pengetahuan baik dan cukup belum tentu mempraktikkan atau melakukan tindakan vulva hygiene dalam perilakunya. Karena seseorang dalam menentukan sikap dan perilaku yang utuh selain ditentukan oleh pengetahuan, juga dipengaruhi oleh pikiran, keyakinan dan emosi yang memegang peranan penting.

Selain itu penelitian yang dilakukan Sari (2007) pada 62 responden di rumah singgah Yms Bandung menunjukkan bahwa ada hubungan yang signifikan antara pengetahuan dengan perilaku personal hygiene.

Pengetahuan yang kurang tentunya akan menyebabkan perilaku yang kurang baik dan akan meningkatkan resiko terganggunya keseimbangan kelembaban di daerah vagina terlebih saat mentsruasi, jika perempuan tidak memperhatikan kebersihan daerah vagina dengan baik akan munculah beragam keluhan yang dapat menyebabkan terjadinya pruritus vulvae. Pemberian pengetahuan yang baik tentang kesehatan reproduksi terhadap remaja tentunya akan berdampak baik dalam mencegah terjadinya pruritus vulvae. Banyak pengetahuan kebersihan organ reproduksi yang dapat dilakukan remaja dalam menjaga kebersihan vagina khususnya saat menstruasi.

\section{Hubungan perilaku tentang vulva hygiene saat menstruasi dengan kejadian pruritus vulvae}

Berdasarkan hasil tabulasi silang perilaku dengan kejadian pruritus vulvae menunjukkan bahwa 50 remaja putri dengan perilaku vulva hygiene kurang sebanyak 47 
orang (94\%) mengalami pruritus vulvae dan 3 orang (6\%) tidak menglami pruritus vulvae. Sedangkan 22 orang yang memiliki perilaku yang cukup sebanyak 12 orang (54,5\%) mengalami pruritus vulvae dan 10 orang $(45,5 \%)$ tidak mengalami pruritus vulvae. Dan 7 orang yang memiliki perilaku baik sebanyak 7 orang (100\%) tidak mengalami pruritus vulvae.

Dengan demikian dapat disimpulkan bahwa perilaku remaja putri tentang vulva higiene berpengaruh terhadap kejadian pruritus vulvae saat menstruasi. Hal ini sesuai dengan hasil penelitian Indah (2012) yang dilakukan pada siswi kelas $\mathrm{X}$ dan $\mathrm{XI}$ di SMAN 1 Ngimbang Lamongan menunjukkan bahwa dari 79 responden, sebanyak 33 responden yang memiliki praktik hygiene menstruasi yang baik, tidak mengalami pruritus vulvae saat menstruasi, dan dapat disimpulkan bahwa ada hubungan antara praktik hygiene menstruasi dengan kejadian pruritus vulvae saat menstruasi.

Perilaku merupakan hal yang dapat menyebabkan pruritus vulvae. Wanita yang mengalami pruritus vulvae sering kali memiliki perawatan vulva yang kurang baik. Perlu diketahui kebiasaan pribadi yang dilakukan oleh responden yang dapat menyebabkan seseorang mengalami pruritus vulvae, contohnya seperti pemakaian sabun untuk membersihkan organ genitalia, pemakaian produk kesehatan wanita seperti pembersih daerah kewanitaan celana dalam yang ketat, kondisi daerah genital yang sering lembab dan tidak bersih.

Hasil penelitian dilapangan menunjukkan bahwa perubahan perilaku hygiene menstruasi yang baik sangat dibutuhkan untuk meningkatkan kesehatan reproduksi dan mencegah terjadinya pruritus vulvae. Perilaku atau kebiasaan buruk yang dilakukan remaja putri dalam menjaga kebersihan genitalia eksterna saat menstruasi seperti membersihkan alat kelamin dari arah belakang ke depan, menggunakan sabun daun sirih, menggunakan celana dalam yang ketat saat menstruasi, dapat memicu berkembangbiaknya jamur ataupun bakteri, hal ini akan berdampak pada kejadian pruritus vulvae.

\section{KESIMPULAN}

Dari hasil penelitian didapatkan skesimpulan : (1) Sebagian besar tingkat pengetahuan remaja putri kelas VII di SMPN 1 Sepulu Bangkalan tentang vulva hygiene dalam kategori kurang sebanyak 41 responden (51,9\%); (2) Sebagian besar tingkat perilaku remaja putri di SMPN 1 Sepulu Bangkalan tentang vulva hygiene dalam kategori kurang sebanyak 50 responden (63,3\%); (3) Kejadian pruritus vulvae saat menstruasi pada remaja putri kelas VII SMPN 1 Sepulu sebanyak 59 responden (74,7\%); (4) Ada hubungan signifikan antara pengetahuan $(p(0,028)<\alpha$ $(0,05))$ dan perilaku $(p(0,006)<\alpha(0,05))$ tentang vulva higiene saat menstruasi 
dengan kejadian pruritus vulvae pada remaja putri kelas VII di SMP Negeri 1 Sepulu Bangkalan.

\section{DAFTAR PUSTAKA}

Ayu, HK. (2010). Aplikasi Praktis Asuhan Keperawatan Keluarga. Jakarta: Sagung Seto.

BKKBN. (2011). Survei Perilaku Beresiko Yang Berdampak Pada Kesehatan Reproduksi Remaja 2. http://www. Scholar. Google. bkkbn.co.id (diakses pada 20 Desember, 2016).

Djajakusumah, T.S. (2011). Penatalaksanaan Pruritus Anogenital. https://www.scribd.com/doc/299292 04737/Pruritus Anogenital, diakses pada tanggal 6 November 2016.

Fitriyah, I (2014). Gambaran perilaku higiene menstruasi pada remaja putri di sekolah dasar negeri diwilayah kerja puskesmas pisangan. file:///C:/Users/Stikes\%20ISA/Downl oads/IMAROTUL\%2OFITRIYAH fkik\%20(8). pdf, diakses tanggal 17 desember 2016.

Indah, FTN. (2012). Kejadian pruritus vulvae saat menstruasi pada remaja. http://download.portalgaruda.org/arti cle.php?article $=134562 \& \mathrm{val}=1122$, diakses tanggal 16 Oktober 2016

Kumalasari, I \& Andyantoro. (2012). Kesehatan Reproduksi Untuk Mahasiswa Kebidanan Dan Keperawatan. Salemba Medika; Jakarta

Laila N, N. (2011). Buku pintar menstruasi, Semarang: Buku biru

Maidartil, dkk. (2016). Hubungan Pengetahuan Dengan Perilaku Vulva Hygiene Pada Saat Menstruasi Remaja Putri.
file:///C:/Users/Stikes\%20ISA/Downl oads/405-1043-1-PB.pdf, diakses tanggal 17 Oktober 2016.

Notoadmodjo, S. (2012). Metodologi Penelitian Kesehatan. Jakarta; Rieneka Cipta

Prawirohardjo, S. (2009). IImu Kandungan. Jakarta: PT. Bina Pustaka.

Pribaki, B. (2014). Menjaga Miss V Tetap Sehat Sexy Siip. Surabaya: Pena Semesta.

Winerungan E M. (2013). Hubungan Pengetahuan Kesehatan Reproduksi Dengan Kejadian Iritasi Vagina Saat Menstruasi Pada Remaja Di SMP Negeri 8 Manado. http:// ejournal. unsrat.ac. id/index. Php /jkp/article/view/2180/1738. diakses tanggal 17 November 2016. 